\title{
PSYCHOLOGICAL WELL-BEING NARAPIDANA REMAJA \\ DI LEMBAGA PEMASYARAKATAN KELAS IIA SIDOARJO
}

Vivi Widya Susanti

Mahasiswa Fakultas Psikologi Universitas Muhammadiyah Sidoarjo Effy Wardati Maryam

Dosen Fakultas Psikologi Universitas Muhammadiyah Sidoarjo. Telp. 08123009392

\section{ABSTRACT}

The entry of youth into the prisons would lead them to the loss of independence, difficulties in adapting, and lonely feeling, which ultimately affects the condition of psychological well-being. Here, psychological well-being is an essential condition to make teenagers, i.e., convicts, be able to defend their lives for serving a sentence. The study aims to provide an overview of the psychological well-being of juvenile prisoners and to investigate the factors that influence the formation of psychological well-being. In this case, the study employs an exploratory qualitative approach to the subject of two teenage inmates. The prison chosen is located in Class II A Sidoarjo. The data are obtained from interviewing technique and field notes. The results show that inmates have bette psychological well-being than when they entered the prison early. The condition is proved at the subjects' ability to adjust themselves to the environment, develop self-potential, accept themselve in a positive attitude, self-control and self-reliant, have a purpose to live and be able to establish positive relationships with others. Meanwhile, the factors that influence the formation of psychological well-being in inmates are social support, social interaction, and social skills while they are in a prison.

Keywords: psychological well-being, inmates, youth

\section{ABSTRAK}

Masuknya remaja ke dalam Lembaga Pemasyarakatan akan menyebabkan kehilangan kebebasan, kesulitan dalam menyesuaikan diri, dan merasa kesepian, yang akhirnya berdampak pada kondisi psychological well-being. Psychological well-being merupakan kondisi yang sangat penting agar narapidana remaja bisa tetap menjalani kehidupannya selama menjalani masa hukuman. Penelitian ini bertujuan untuk memberikan gambaran mengenai psychological wellbeing narapidana remaja serta untuk mengetahui faktor-faktor yang mempengaruhi terbentuknya psychological well-being. Penelitian ini menggunakan pendekatan kualitatif eks-ploratif cen Sido Sidoarjo. Penggalian data dengan teknik wawancara dan catatan lapangan. Hasil penelitia menunjukkan bahwa narapidana remaja dalam penelitian ini memiliki gambaran psychological well-being yang baik dibandingkan ketika awal memasuki Lembaga Pema-syarakatan. Hal in terlihat pada kemampuan subjek dalam menyesuaikan diri dengan lingkungan, mengembangkan potensi diri, menerima diri secara positif, mengontrol diri dan mandiri, memiliki tujuan hidup serta mampu menjalin hubungan positif dengan orang lain. Faktor-faktor yang mempengaruh terbentuknya psychological well-being pada narapidana remaja adalah dukungan sosial, interaks sosial, dan keterampilan sosial yang dimiliki subjek selama berada di Lembaga Pemasyarakatan.

Kata kunci : psychological well-being, narapidana, remaja 


\section{PENDAHULUAN}

Membahas mengenai permasalahan remaja seperti tidak ada habisnya. Masa re-maja merupakan masa "Strum and Drangn yaitu merupakan periode yang berada dalam dua situasi: antara kegoncangan, penderitaan, asmara, dan pemberontakan dengan otorita orang dewasa (Hall dalam Yusuf, 2011). Beberapa kasus kriminal yang melibatkan remaja sering menjadi sorotan dalam pemberitaan di media massa, baik media cetak maupun media elektronik. Hal ini seakan menandai bahwa masa remaja merupakan masa yang rentan terhadap permasalahan.

Fase remaja merupakan segmen perkembangan individu yang sangat penting, dia-wali dengan matangnya organ-organ fisik (sek-sual) sehingga mampu bereproduksi (Yusuf, 2011). Menurut Muss (dalam Sar-wono, 20-07) emaja dalam arti adolescence berasal dar kata latin adolescere yang arti-nya tum-buh kearah kematangan. Kematangan dalam hal ini tidak hanya berarti kematangan fisik, tetapi terutama kematangan sosial-psi-kologis. Santrock (2003) mengungkapkan balo Sescence diatikan sebaga masa pc lescence diastikan sebagai masa perkemcen dewasa yang mencakup perubahan bio-logis, kognitif, dan sosial- emosiona

Berdasarkan Kamus Lengkap Psiko-log (Chaplin, 2009), periode antara pubertas da kedewasaan (adolescence) berkisar anta-ra usia 12 sampai 21 tahun untuk anak gadis (perempuan) dan usia 13 sampai 22 tahun (20gi anak laki-laki. Sedangkan menurut Monks (2006), masa remaja dibagi menjadi tis baian yaitu masa remaja awal (12-15 (anin), yoitu masa renaja awal (12-15 tahun), masa remaja pertengahan (15-18 tahun) dan masa remaja akhir (18-21 tahun). Batas-batas usia ini menandai adanya perubahan-perubahan baik fisik maupun psikologis yang terjadi pada individu remaja. Perubahan yang terjadi meliputi adanya perkembangan seksual yang ditandai dengan kematangan organ seksual yang sudah dapat berfungsi sepenuhnya untuk mengembangkan keturuman (Sarwono, 2010) serta munculnya tugas-tugas perkembangan yang akan dilalui oleh remaja untuk mencapai kemampuan bersikap dan (Hurlock, 2007). Namun tidak semua remaja dapat memenuhi tugas-tugas tersebut dengan baik, menurut Hurlock (2007) ada beberapa permasalahan yang dialami remaja terkait dalam pemenuhan tugas-tugas tersebut, yaitu 1) pribadi, yaitu masalah-masalah yang erhubungan dengan situasi dan kondisi di rumah, sekolah, kondisi fisik, penampilan, emosi, penyesuaian sosial, tugas dan nilai-nilai, 2) masalah khas remaja, yaitu masalah yang timbul akibat status yang tidak jelas pada remaja, seperti masalah pencapaian kemandirian, kesalahpahaman atau penilaian berdasarkan stereotip yang keliru, adanya hak-hak yang lebih besar dan lebih sedikit kewajiban dibebankan oleh orangtua.

Data dari Komisi Nasional Perlin-dungan Anak untuk tahun 2011 terdapat 528 kasus kejahatan yang dilakukan oleh anak, mulai dari anak Sekolah Dasar (SD) hingga Sekolah Menengah Atas (SMA), dan kejahatan palin banyak dilakukan oleh anak SMA sebesar 24 kasus. Adapun kasus kejahatan yang dilakukan bervariatif mulai dari perko-saan, pelecehan seksual, kekerasan, pembu-nuhan dan penculikan (www.komnaspa.or.id, 2012)

Adanya perubahan dan perkembangan baik secara fisik maupun psikologis menuntut remaja untuk dapat menyesuaikan diri dalam lingkungan dan tantangan hidup yang ada dihadapannya, sehingga hal ini seringkal membuat remaja terjebak melakukan hal-ha yang melanggar norma hukum yang berlaku dalam masyarakat. Remaja yang kurang atau tidak mendapat perhatian secara fisik, menta maupun sosial sering berperilaku dan bertindak antisosial yang merugikan dirinya, keluarga, dan masyarakat, sehingga tidak sedikit remaja yang menjadi pelaku tindak pidana.

Data Komisi Nasional Perlindungan Anak, sepanjang tahun 2011 menerima 1.851 pengaduan anak yang berhadapan dengan hukun (anak sebagai pelaku) yang diajukan ke pengadilan. Angka ini meningkat diban-ding pengaduan pada tahun 2010, yakni 730 kasus. Hampir $52 \%$ dari angka tersebut adalah kasus pencurian diikuti dengan kasus perkosaan, narkoba, perjudian, serta peng niayaan dan hampir $89,8 \%$ kasus anak yan berhadapan dengan hukum berakhir pada pemidanaan atau diputus pidana (www.komnaspa.or.id, 2012). Meningkatknya data prosentase pemidanaan ini dibuktikan dadiperkut oleh data anak yang tersebar di 16 diperkat on di 16 Lenbag 6.505 anak yang bethape mukan 6.505 anak yang berhadapan dengan hukum diajukan ke pengadilan, dan 4.622 ana diantaranya saat ini mendekam dipenjara. Jumlah ini mungkin jauh lebih besar karen angka ini hanya bersumber dari laporan 29 Bapas (Balai Pemasyarakatan), sementara di Indonesia terdapat 62 Balai Pemasyarakatan (www.kemenkumham.go.id, 2012).

Kehidupan di Lembaga Pemasyaraka-tan yang serba dibatasi oleh peraturan-peraturan embaga membut narapidana ke-sulita

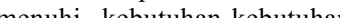
seperti ketika mereka masih berada di luar Lembaga Pemasyarakatan. Hasil penelitian yang dilakukan Handayani (2010) menemuka bahwa ketiga subyek narapidana remaja yang diteliti di Lembaga Pemasyara-katan mengalami kondisi yang tidak sehat secar psikologis yakni adanya perasaan ketidakperdayan diri menghadapi kondisi yang

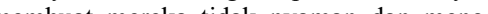
kibatkan mereka ticen nyaman dan mengadisi yang diala i tama berusana kondisi yang dialami tanpa berusaha untuk mengembangkan kemampuan yang dimilik untuk bisa mencapai kondisi yang lebih baik. Kehidupan seorang narapidana anak dan narapidana remaja di Lembaga Pemasyara-kata tentunya berbeda dengan kehidu-pan temanteman seusianya yang tinggal di luar Lembaga Pemasyarakatan. Mereka tidak dapat merasakan kebebasan seperti kehidupan di luar Lembaga Pemasyarakatan. Kondisi ini dikemukakan Mulyadi (dalam Handayani 2010) sebagai akibat bahwa pidana penjara merupakan pidana bersifat perampasan kemerdekaan pribadi terpidana karen penempatannya dalam bilik penjara. Kehilagan kemerdekaan itu antara lain hilangnya hubungan heteroseksual (loos of heterosexual), hilangnya kebebasan (loos of autono- $m y$ ), hilangnya pelayanan (loos of good and servicce), dan hilangnya rasa aman (loos of security), di samping kesakitan lain, seperti akibat prasangka buruk dari masyarakat (moral rejection of the inmates bysociety) (Sykes, dalam Handayani 2010).

Selain itu, standar hidup disebagian Lembaga Pemasyarakatan belum layak, seperti satu ruang tahanan yang harus dihuni oleh sejumlah besar narapidana, minimnya air bersih, pelayanan kesehatan yang terbatas dan sanitasi yang buruk (Haryadi dalam Yudianto, 2011), diyakini berpengaruh dalam memenuh kebutuhan hidup remaja sebagai manusia.

Berdasarkan konsep pemenuhan kebutuhan hidup manusia, Maslow (dalam Alwisol, 2007) membuat hirarki kebutuhan yang tersusun dari lima kebutuhan dasar manusia. Kebutuhan-kebutuhan tersebut adalah kebutuhan fisiologis yang meliputi kebutu-han biologis, kebutuhan keamanan dan keselamatan, kebutuhan sosial, kebutuhan penghar-gaan diri, dan kebutuhan aktualisasi diri. Jik kebutuhan-kebutuhan ini tidak terpenuhi dengan baik, maka individu akan merasa tidak bahagia. Seberapa tinggi individu mendapatkan pemenuhan kebutuhannya sedemikian pula derajat kebahagiaan seseorang, hal in terkait dengan apa yang diinginkannya, ap yang telah diperolehnya, dan apakah yang dimiliki oleh orang-orang yang berhubungan dengannya. Dengan kata lain, kebahagiaan terjadi setelah kebutuhan terpenuhi dan apa yang menjadi tujuannnya tercapai karena kebahagiaan dikatakan sebagai tujuan akhi dari seluruh aktivitas (Sarwono, 2008)

Perasaan bahagia serta adanya kepua-san hidup dan realisasi diri inilah yang dise-but dengan Psychological Well-Being (Yu-dianto, 2011). Bagi narapidana remaja, Psy-chological Well-Being merupakan kondisi yang penting ar do dengan dimiliki nanti.

Ryff (dalam Karyono, dkk., 2008) mengemukakan bahwa pondasi untuk memperole kesejahteraan psikologis adalah individu yang secara psikologis dapat memiliki fungsi 
secara positif (positive psycholo-gical functioning). Komponen individu yang mempunyai fungsi psikologis yang positif yaitu: (1) Penerimaan diri (self-acceptance), (2) Hubungan positif dengan orang lain (positive relations with others), (3) Otonom (autonomy), (4) Tujuan hidup (purpose in life), (5) Perkembangan pribadi (personal growth),

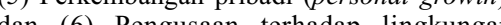
(enviro Pentasas tery). Jik renaja (environmental mastery). Jika remaja yan sedang menjalani masa hukumannya di dalam penjara mampu memenuhi komponenkomponen tersebut dengan baik maka individ tersebut akan memiliki Psychological WellBeing yang tinggi. Sebaliknya, jika individu belum mampu memenuhi komponen-komponen tersebut dengan baik maka dapat dikatakan individu tersebut belum memiliki fungsi positif secara psikologis (PsychologicalWellBeing rendah)

Psychological Well-Being yang kurang baik akan memunculkan perasaan ketidakmampuan dalam diri narapidana sehingg akan menghambat narapidana remaja dalan memaksimalkan potensi yang dimiliki. Ole karena itu, penulis tertarik untuk mengetahui bagaimana gambaran Psychological WellBeing yang dimiliki oleh narapidana remaja Lemba Pemasyarakatan jo sebagai bentuk pengembangan dari penelitian yang sudah ada.

\section{METODE PENELITIAN}

Penelitian ini menggunakan tipe penelitian kualitatif. Secara spesifik penelitian kali in menggunakan tipe penelitian eksploratif. Penelitian kualitatif adalah suatu proses penelitian ilmiah yang dimaksudkan untuk memahami masalah-masalah manusia dalam konteks sosial dengan menciptakan konteks sosial dengan menciptakan disajikan, melapork dan kompleks yang dis dari para sumber informasi, serta dilakuka dalam settingyang alamiah tanpa adany intervensi apa pun dari peneliti (Creswell dalam Herdiansyah, 2010). Sedangkan eksploratif (bersifat eksplorasi) artinya bahwa penulis berusaha menemukan atau mengungkapkan permasalahan yang akan diteliti ata 
seseorang untuk bersikap positif terhadap diri sendiri dan kehidupan yang dijalani. Ha tersebut menandakan Psychological WellBeing yang tinggi (Ryff dalam Deci dan Ryan, 2001). Ryff menambahkan bahwa individu yang memiliki tingkat penerimaan diri yan baik ditandai dengan sikap yang baik terhadap diri sendiri, mengetahui dan menerima segala la aspek yang ada pach dinny, baik kelebihan maupun kekurangan, serta memiliki sikap baik terhadap kehidupan di masa lalu. Dahlan (dalam Manik, 2007), menjelaskan bahwa remaja yang melakukan tindak kriminal dan dijebloskan ke dalam penjara akan merasa tidak berharga dibanding anak seusianya yang lain, mendapat celaan dari orang lain, merasa tidak punya harapan, merasa gagal sehingga menimbulkan depresi dan terlebih kurangnya dukungan eluarga, individu akan menyalahkan dirinya sendiri dan menganggap tidak ada yang menyayanginya sehingga jika keadaan ini terus menerus berlanjut maka individu dapat memiliki penerimaan diri yang negatif. Hasil wawancara dengan subjek dalam penelitian ini menunjukkan bahwa subjek meyadari kesalahan yang telah diperbuatnya telah merugikan dirinya dan keluarga. Subjek berkeinginan untuk memperbaikikesalahannya dimasa yang akan datang.

Dimensi kedua adalah personal growth (perkembangan pribadi). Ryff (dalam Deci dan Ryan, 2001) menjelaskan pertumbuhan pribadi adalah kemampuan individu untuk mengembangkan potensi dalam diri dan berkembang sebagai seorang manusia. Dimensi ini dibutuhkan oleh individu aga dapat optimal dalam berfungsi secara psikologis. Maslow (dalam Alwisol, 2007) menambahkan bahwa orang yang sehat adalah oran yang mengembangkan potensi positifny mengikuti jalur perkembangan yang sehat dirinya daripada mengikuti pengaruh lingkungan iluar dirinya. Dimensi ini nampa pada narapidana remaja dalam penelitian in yang menekuni dan mengembangkan beberapa kegiatan yang bersifat positif selama di dalam Lembaga Pemasyarakatan, antara lain ketrampilan (kerajinan tangan), aktif mengikut kebaktian di gereja, mengikuti penyuluhan tentang narkoba, dan aktif sebagai pengurus perpustakaan Lembaga Pemasyarakatan.

Dimensi ketiga yaitu tujuan hidup (purpose of life), menjelaskan mengenai kemampuan individu untuk mencapai tujuan dalam hidup. Seseorang yang memiliki rasa keterarahan Sescon yup, enich pasan rarti, da memiliki target yang ingin dicapai dalam hidup maka individu dapat dikatakan memiliki tujua hidup yang baik (Ryff, dalam Deci dan Ryan, 2001). Berdasarkan wawancara dengan subjek penelitian, diperoleh hasil bahwa mereka memiliki keinginan untuk menjalankan usah (wiraswasta) dengan orang tua setelah keluar dari Lembaga Pemasyarakatan.

Penguasaan terhadap lingkungan (environmental mastery) sebagai dimensi keempat dari Psychological Well-Being menjelaskan tentang kemampuan untuk memanipulasi keadaan sehingga sesuai dengan kebutuhan dan nilainilai pribadi yang dianutnya dan mampu untuk mengembangkan diri secara kreatif melalui aktivitas fisik maupun mental. Individu dengan Psychologycal Well-Being yang baik memiliki kemampuan untuk memilih dan menciptakan lingkungan yang sesuai dengan kondisi fisik dirinya. Dengan kata lain, individu mempunyai kemampua lain, ench dalam (Ryfr, diriny Ryff, dalam Deci dan Ryan, 2001). Saputra (dalam Handa-yani, 2010) menggambarka bahwa terdapat beberapa permasalahan kesehatan fisik para narapidana berkaitan dengan kondisi makanan, yaitu kurang terpenuhinya gizi, sedangkan permasalahan kesehatan psikis digambarkan dengan adanya berbagai tekanan di Lembaga Pemasyarakatan, meliputi kekurangan kualitas fasilitas, dan makin padatny peng-huni Lembaga Pemasyarakatan. Kondisi tersebut menjadi penyebab utama terganggunya kondisi kesehatan para narapidana penghuni Lembaga Pemasyarakatan, baik itu kesehatan fisik, maupun kesehatan psikologi (Rininta, dkk., dalam Handayani, 2010).

Narapidana remaja pada penelitian ini awalnya cenderung merasa takut dan cemas dengan lamanya masa hukuman yang akan dijalani, ditambah lingkungan di dalam Lembaga Pemasyarakatan yang serba dikondisikan oleh peraturan-peraturan yang ketat. Selain itu, narapidana remaja dalam penelitian ini jug cenderung merasa kesulitan dalam melakukan penyesuaian diri dengan lingkungan bar yang didominasi oleh orang dewasa daripada yeusion subjek subjek sudah merasa mi Lembaga Pemasyadengan lingkungan di Lembaga Pemasyarakatan dengan berbaur bersama narapidan lain dan mengikuti segala peraturan-peraturan yang berlaku. Dimensi ini juga nampak pada kemampuan narapidana remaja dalan penelitian ini yang bisa memenuhi kebutuhan makanannya sendiri tanpa bergantung kepada jatah makanan dari Lembaga Pemasyarakatan atau kiriman dari keluarga.

Dimensi kelima adalah otonomi (autonomy). Ryff (dalam Deci dan Ryan, 2001) menyebutkan bahwa dimensi otonomi menjelaskan mengenai kemandirian, kemampua untuk menentukan diri sendiri, dan kemanpuan untuk mengatur tingkah laku. Seseorang yang mampu untuk menolak tekanan sosial untuk berpikir dan bertingkah laku dengan cara-cara tertentu, serta dapat mengevaluasi diri sendiri dengan standar personal, hal ini menandakan bahwa individu baik dalam dimensi ini. Sebaliknya, individu yang kurang baik dalam dimensi otonomi akan memperhatikan harapan dan evaluasi dari orang ain, membuat keputusan berdasarkan penlaian orang lain, dan cenderung bersikap konformis. Keterampilan remaja dalam mengambil keputusan tidak berbeda dengan kemampuan orang dewasa, hal ini dianggap mempunyai dampak penting untuk mengurangi pengambilan resiko pada remaja dan peningkatan keschatan (Quadrel, Fishcoff dan Davis, dam Sant 2003). Dimens ini sudah tercapai oleh subjek dalam penelitian ini, yait dengan mampu membuat beberapa keputusan sendiri tanpa bergantung kepada orang lain.

Dimensi terakhir adalah Positive Relation with Others (hubungan positif dengan oran lain). Kartono (dalam Yudianto, 2011) menjelaskan bahwa kehidupan yang berjalan di dalam penjara memiliki kebudayaan tersendir dan dalam kalangan narapidana terdapat norma-norma, hukum-hukum, kontrol dan sanksisanksi sosial serta bahasa dengan logat dan kode tersendiri. Narapidana remaja dalan penelitian ini berupaya untuk menye-suaikan diri dengan lingkungan Lembaga Pemasyarakatan yang didominasi oleh orang dewasa Sesuai dengan pendapat Dayakisni (2009) bahwa keingin dan Hudain dengan orang lain pada umumny dilandasi adanya imbalan sosial yang dapa diperoleh individu jika berhubungan dengan orang lain. Selain itu diantara pencapaian-pencapaian kebutuhan dalam proses menuju dewasa, intimasi adalah faktor yang paling penting (Sullivan, dalam Alwisol, 2007). Menurut Safin, Williams dan Berndt (dalam Santrock, 2003), meskipun kebanyakan remaja

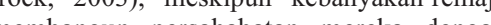
in indidu yang dekat dengan usia mereka beberat bag individu yang lebih muda atau lebih tua. Membina hubungan yang hangat dengan orang lain merupakan salah satu dari criterion of maturity yang dikemukakan oleh Sullivan (dalam Alwisol, 2007). Ryff (dalam Deci dan Ryan, 2001) juga menekankan pentingnya menjalin hubungan saling percaya dan hangat dengan orang lain.

Penelitian yang pernah dilakukan Yu-dianto (2011) menemukan bahwa narapidana yan telah menjalani masa hukuman penjara lebih dari satu tahun cenderung memiliki penerimaan diri yang lebih positif, hal ini dipengaruhi oleh adanya dukungan dari orang terdekat seperti keluarga, teman dan kekasih. Maslow (dalam Alwisol, 2007), berpendapat bahwa manusia sangat peka dengan kesendi-rian, pengasingan, ditolak lingkungan, dan kehilangan cinta. Dicintai dan diterime adalah jalan menuju peran yang sehat dan berhar-ga. Sebagai eorang remaja, dukungan dari orang lain akan membantu remaja keluar dari perasaan sulit yang sedang dialaminya, sesuai dengan pendapat Eccles, dkk., (dalam San-trock, 2003) bahwa masing-masing dari kita yang berhubungan dengan remaja; seba-gai orang dewasa, orang tua, pekerja untuk remaja, professional, dan pendidik, dapat membantu

112 PSIKologila / Vol. : 2, No. : 1, Januori 2013 
memperbaiki kesehatan dan kesejahteraan mereka.
Perkembangan Suatu Pendekatan Sepanjang Rentang Kehidupan Edis Kelima. Jakarta : Erlangga.

Karyono, dkk., (2008). Penanganan Stress dan Kesejahteraan Psikologis Pasien Kanker Payudara yang Menjalani Radio Terapi di RSUD Dr. Moewardi Surakarta Fakultas Kedokteran Universitas Fakultas Kedokteran Universitas Indonesia Wilayah Jawa Indoni Tengah. Media Medika Indonesia. Volume 43, Nomor 2, 102-105

Kasus Anak yang Berhadapan dengan Hukum. (2011). Diakses pada 10 Maret 2012, dari: http://www.komnaspa.or.id

Monks, F. J., \& Haditono, ( 2006 ). Psikologi Perkembangan. Yogyakarta: Gajah Mada University Press.

Poerwandari, K., (2009). Pendekatan Kualitatif untuk Penelitian Perilaku Manusia. Lembaga Pengembangan Saran Pengukuran dan Pendidikan Psikologi: Pengukuran dan Pendidikan Psikologi:
Fakultas Psikologi Universitas Indonesia.

Alwisol (2007). Psikologi Kepribadian Edis Revisi. Malang: UMM Press.

Bungin, H. M. Burhan., (2005). Metode Penelitian Kuanitatif. Komunikasi, Ekonomi dan Kebijakan Publik Serta Ilmu-Ilmu Sosial Lainnya. Jakarta: Kencana.

Chaplin, J. P., (2009). Kamus Lengkap Psikologi. Jakarta: PT. Raja Grafindo Persada.

Dayakisni, T. Hudaniah (2012). Psikologi Sosial.Cetakan Kelima. Malang: UMM Press.

Deci, E. L. dan Ryan, R. M., (2001). On Happiness And Human Potentials: A Review Of Research On Hedonic And Eudaimonicwell-Being. Journal of Annual Reviews University of Illinois, Chicago 2001, Volume 52, No.141166. 166. Psikologis Narapidana Remaja di Lembaga Pemasyarakatan Kutoarjo. (Ringkasan Skripsi, Fakultas Psikologi Universitas Diponegoro Semarang)

Herdyansyah, H., (2010). Metodologi Sosial. Jakarta: Salemba Humanika.

Hurlock, E. B., (2007). Psikologi
Santrock,J.W, (2003). Adolescence: Erlangga

Sarwono, S. W.,(2007). Psikologi Remaja Edisi Revisi. Jakarta: PT Raja Grafindo Persada

Sarwono, S.W., (2010). Pengantar Psikologi Umum. Jakarta : PT Rajawali Pers.

Snyder, C. R., \& Lopez, S. J., (2002) Handbook of Positive Psychology. New York Oxford University Press Perkembangan Remaja. Jakarta: 